\title{
SYNTHESIS AND CHARACTERIZATION OF ZNO THIN FILMS DEPOSITED BY CHEMICAL BATH TECHNIQUE
}

\author{
I. Nkrumah" ${ }^{* 1}$, F.K. Ampong ${ }^{2}$, B. Kwakye-Awuah ${ }^{3}$, R.K. Nkum ${ }^{4}$, F. Boakye ${ }^{5}$ \\ ${ }^{I}$ Department of Physics, Kwame Nkrumah University of Science and Technology, Kumasi, Ghana \\ ${ }^{2}$ Department of Physics, Kwame Nkrumah University of Science and Technology, Kumasi, Ghana \\ ${ }^{3}$ Department of Physics, Kwame Nkrumah University of Science and Technology, Kumasi, Ghana \\ ${ }^{4}$ Department of Physics, Kwame Nkrumah University of Science and Technology, Kumasi, Ghana \\ ${ }^{5}$ Department of Physics, Kwame Nkrumah University of Science and Technology, Kumasi, Ghana \\ inkrumah.sci@knust.edu.gh,fkampong.cos@knust.edu.gh,bkwakye-awuah.cos@knust.edu.gh, \\ rnkum.cos@knust.edu.gh,fboakye.sci@knust.edu.gh
}

\begin{abstract}
$\mathrm{ZnO}$ thin films have been deposited on silica glass substrate using the chemical bath deposition technique. The precursors used were zinc chloride and aqueous ammonia. The solution was stirred continuously with the help of a magnetic stirrer at a bath temperature of $70^{\circ} \mathrm{C}$ and a deposition time of 70 minutes. The elemental composition and the surface morphology were studied using energy dispersive and scanning electron microscopy. The band gap was 2.72, 2.66, $2.60 \mathrm{eV}$ for as-deposited, annealed at $200^{\circ} \mathrm{C}$ and $300^{\circ} \mathrm{C}$ respectively. There was a red shift in the band gap energy as the annealing temperature was increased. This might be due to an improvement in the crystallinity of the $\mathrm{ZnO}$ thin films.
\end{abstract}

Index Terms: Zinc oxide, chemical bath, band gap, annealing

\section{INTRODUCTION}

Zinc oxide $(\mathrm{ZnO})$ is a wide band gap semiconductor material (Raidou et al, 2010) and it is a versatile and an important technological material. $\mathrm{ZnO}$ has many applications that include transparent electrodes [Teng et al, 2006, Young-Sung et al, 2005], piezoelectric [Ajayan el al, 2010], light emitting diode [Jae-Hong et al, 2006], photovoltaic devices [Singh et al, 2011], gas sensors [Suchea et al, 2006], solar cells [Shen et al, 2010; Lupan et al, 2009; Park et al, 2012] and dye-sensitized solar cells [Thitima et al, 2009], ultraviolet sensor [Panda and Jacob, 2012].

Many methods have been used to deposit $\mathrm{ZnO}$ for various applications. They include ac magnetron sputtering [Bernède et al, 2008], dc magnetron sputtering [Abduev et al, 2008; Sutthana et al, 2010], ion implantation [Xu et al, 2012], molecular beam epitaxy [Heo et al, 2006], metal organic chemical vapor deposition [Tan et al, 2005], sol-gel method [Tahar, 2005], spray pyrolysis [El Hichou, 2004] and chemical bath method [Chu et al, 2009]. The chemical bath method has an advantage over other methods since it is very simple, it does not require sophisticated equipment, it uses low temperature and has low cost of deposition [Annuar et al, 2010; Nwodo et al, 2010].
In this paper, thin films of $\mathrm{ZnO}$ have been deposited on silica glass substrate using chemical bath method. The elemental composition and the morphology of the film have been studied. The band gap and the effect of annealing temperature on band gap have also been investigated.

\section{MATERIALS AND METHODS}

The reagents used in this experiment were zinc chloride (from BDH Poole England $98.00 \%$ purity), aqueous ammonia. 0.1 M of zinc chloride was prepared and small drops of ammonia were added and stirred continuously using a magnetic stirrer to obtain optimum $\mathrm{pH}$ of 9.4 for this deposition. $70 \mathrm{ml}$ solution of zinc chloride and aqueous ammonia were put in $100 \mathrm{ml}$ beaker and the substrates whose surface had been prepared under standard conditions were vertically suspended in the beaker and the solution was constantly stirred using magnetic stirrer in a water bath of constant temperature of $70{ }^{\circ} \mathrm{C}$. The deposition time was 70 minutes. After 70 minutes the substrate with deposited thin films were removed, rinsed with distilled water and left to dry. The as-deposited $\mathrm{ZnO}$ thin films were also annealed at $200{ }^{\circ} \mathrm{C}$ and $300{ }^{\circ} \mathrm{C}$ in a furnace.

The films deposited were characterized using energy dispersive X-ray analysis (EDAX) equipment (EDS Genesis 
4000). The surface morphology of the films was observed using scanning an electron microscope (ESEM Quanta 400 FEG, FEI). The absorbance of the film was also measured using UV mini Schmadzu UV-VIS spectrophotometer in the wavelength range 300-1100 $\mathrm{nm}$.

\section{RESULTS AND DISCUSSIONS}

Figure 1 shows the elemental composition of the asdeposited $\mathrm{ZnO}$ thin film. The EDAX spectrum is consistent with the formation of $\mathrm{ZnO}$ on silica glass substrate. Other elements such as $\mathrm{Si}$, Au etc. emanate from the substrate. The scanning electron microscopy (SEM) image of the surface morphology of the as-deposited $\mathrm{ZnO}$ thin film is shown in Figure 2. The image shows nanorods of the $\mathrm{ZnO}$ thin films. The band gap can be determined from the Stern (1963) relation

$$
A h v=k\left(h v-E_{g}\right)^{\frac{n}{2}}
$$

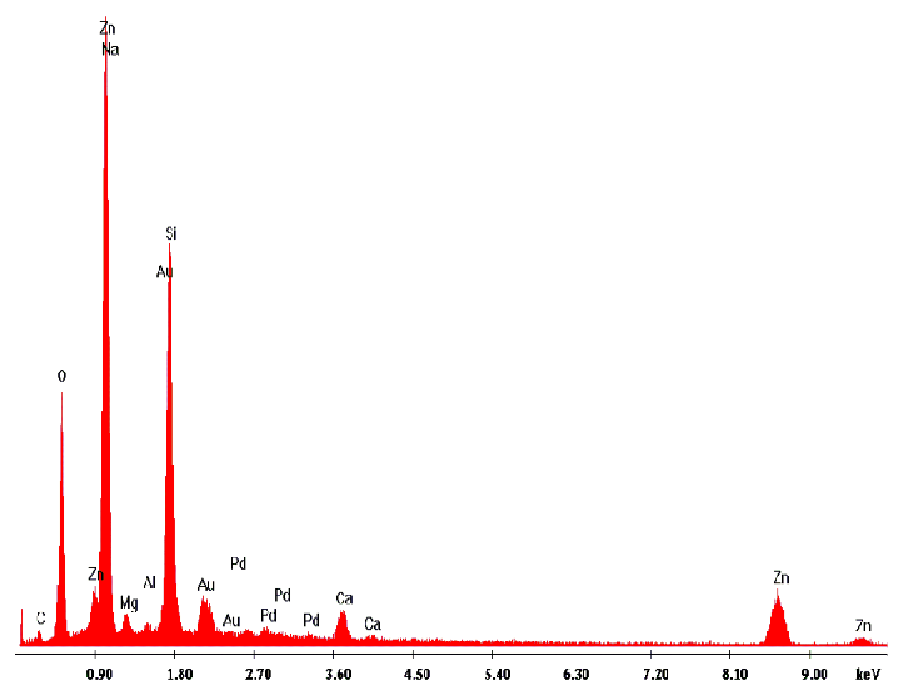

Figure 1: Energy dispersive X-ray analysis (EDAX) analysis of the as-deposited $\mathrm{ZnO}$

where, $\mathrm{A}=$ Absorbance

$\mathrm{h}=$ Planck's constant

$v=$ frequency

$\mathrm{E}_{\mathrm{g}}=$ Band gap

$\mathrm{n}=$ the type of transition $(\mathrm{n}=1$ for direct transition)

$\mathrm{k}=\mathrm{A}$ constant

A plot of $(A h v)^{2}$ against the photon energy hv gives a curve as shown in Figure 3 and extrapolation of the linear portion of the curve to the $h v$ axis gives the band gap $\mathrm{E}_{\mathrm{g}^{*}}$ The band gaps $\mathrm{E}_{\mathrm{g}}$ for as-deposited, annealed at $200{ }^{\circ} \mathrm{C}$ and $300{ }^{\circ} \mathrm{C}$ are respectively $2.72,2.66$ and $2.60 \mathrm{eV}$. The band gap value of 2.72 for as-deposited thin film is comparable to the band gap value obtained by Eya et al (2005). There is a red shift in the band gap values of the as-deposited $2.72 \mathrm{eV}$, annealed at $200{ }^{\circ} \mathrm{C}$ of $2.66 \mathrm{eV}$ and $300{ }^{\circ} \mathrm{C}$ of $2.60 \mathrm{eV}$. This is also in agreement with the works of Elilarassi and Chandrasekaran (2010) and Lv et al, 2011] who also observed a reduction in band gap of $\mathrm{ZnO}$ as the annealing temperature was increased. This might be due to an improvement in the crystallinity of the $\mathrm{ZnO}$ thin films.

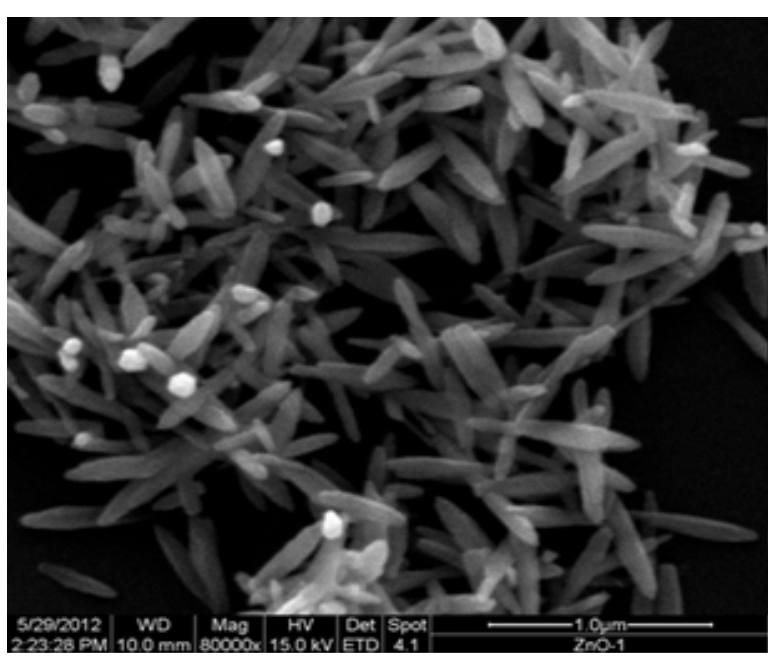

Figure 2: SEM image surface morphologyy of as-deposited $\mathrm{ZnO}$ thin film

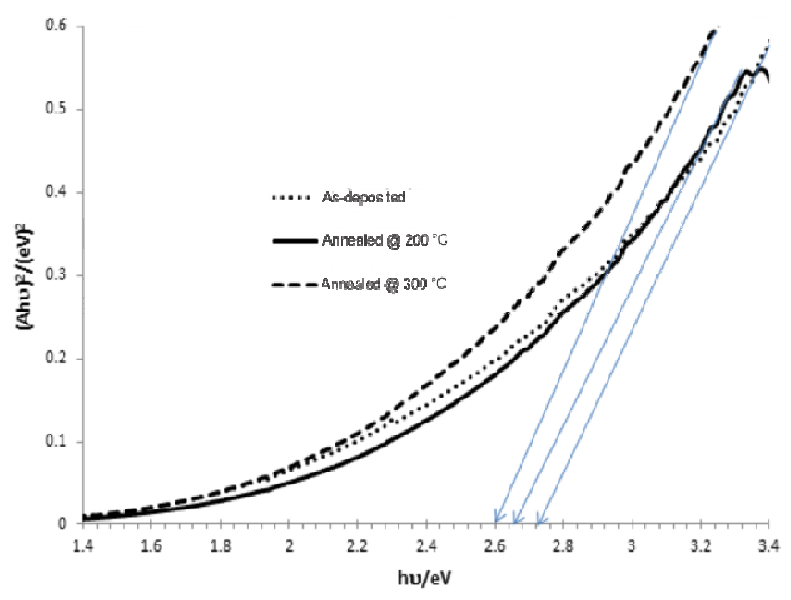

Figure 3: A graph of (Ahv $)^{2}$ versus hv of $\mathrm{ZnO}$ thin film for as-deposited, annealed at $200^{\circ}$ and $300^{\circ} \mathrm{C}$

\section{CONCLUSION}

$\mathrm{ZnO}$ thin films have been successfully deposited on silica glass substrate using chemical bath deposition technique. The elemental composition of the films was studied using energy dispersive X-ray diffraction. The surface morphology of the films was also investigated. The nanorod 
of the as-deposited $\mathrm{ZnO}$ thin film was observed using the scanning electron microscopy. The optical band gap for the as-deposited, annealed at $200{ }^{\circ} \mathrm{C}$ and $300{ }^{\circ} \mathrm{C}$ were respectively $2.72,2.66$ and $2.60 \mathrm{eV}$. There was a red shift in the band gap energy as the annealing temperature was increased. This might be due to an improvement in the crystallinity of the $\mathrm{ZnO}$ thin films.

\section{REFERENCES}

1. Abduev, A., A. Akhmedov., A Asvarov, and A. Abdullaev. 2008. "Investigations of Synthesis of ZnO Thin films in DC Magnetron Sputter Process". Journal of the Korean Society. 53 (1):59-62.

2. Ajayan, P.M., H. Gullapalli, and V. S. M. Vemuru. 2010. "Flexible Piezoelectric ZnO-Paper Nanocomposite Strain Sensor', Small 6 (15):16411646.

3. Annuar, K. T., T. W. Tan, M. S. Ho, M. Shanthi, and N. Saravanan. 2010. "Effect of Bath Temperature on the Chemical Bath Deposition of PbSe Thin Films". Kathmandu University Journal of Science, Engineering and Technology. 6(2):126132.

4. Bernède, J. C., L. Cattin, M. Morsli, and Y. Berredjem. 2008. "Ultra-Thin Metal Layer Passivation of the Transparent Conductive Anode in Organic Solar Cells', Solar Energy Materials and Solar Cells. 92(11):1508-1515.

5. Chu, D., T. Hamada, K. Kata, and Y. Masuda. 2009. "Growth and Electrical Properties of $\mathrm{ZnO}$ Films Prepared by Chemical Bath Deposition Method'. Phys. Status Solidi A 206(4):718-723.

6. El Hichou, A., M. Addou, A. Bougrine, R. Dounia, J. Ebothé, M. Troyon, and M. Amrani. 2004. "Cathodoluminescence Properties of Undoped and Al-doped ZnO Thin Films deposited on Glass Substrate by Spray Pyrolysis'. Materials Chemistry and Physics. 83(1):43-47.

7. Elilarassi, R and G. Chandrasekaran. 2010. "Effect of Annealing on Structure and Optical Properties of Zinc Oxide Films'. Material Chemistry and Physics. 121(1-2):378-384.

8. Eya, D. D.O., A. J. Ekpunobi, and C. E. Okeke. 2005. "Structural and Optical Properties and Applications of Zinc Oxide Thin Films Prepared by
Chemical Bath Deposition Technique', Pacific Journal of Science and Technology. 6(1):16-22.

9. Heo, Y. W., K. Ip, S. J. Pearton, D. P. Norton, and J.D. Budai. 2006. "Growth of $\mathrm{ZnO}$ Thin Films on c-place $\mathrm{Al}_{2} \mathrm{O}_{3}$ by Molecular Beam Epitaxy Using Ozone as an Oxygen Source'. Applied Surface Science. 252:7442-7448.

10. Jae-Hong, L., K. Chang-Ku, K. Kyoung-Kook, P. Il-Kyu, H. Dae-Kue, and P. Seong-Ju. 2006. "UV Electroluminescence Emission from $\mathrm{ZnO}$ LightEmitting Diodes Growth by High-Temperature Radiofrequency Sputtering', Advanced Materials. 18:2720-2724.

11. Lupan, O., S. Shishiyanu, S., Ursaki, V., Khallaf, H., Chow, L., Shishiyanu, T., Sontea, V., E. Monaico, and R. Railean. 2009. "Synthesis of Nanostuctured Al-doped Zinc Oxide Thin Films on Si for Solar Cells Application'. Solar Energy Materials and Solar Cells. 93(8):1417-1422.

12. Lv, J., W. Gong, K. Huang, J. Zhu, F. Meng, X. Song, and Z. Sun. 2011. "Effect of Annealing Temperature on Photocatalytic Activity of $\mathrm{ZnO}$ Thin Films Prepared by Sol-gel Method'. Superlattices and Microstructures 50:98-106.

13. Nwodo, M. O., S. C. Ezugwu, F.I. Ezema, P.U. Asogwa, and R. U. Osuji. 2010. "Chemical Bath Deposition and Characterisation of PVP Capped Tin Oxide Thin Film', Journal of Optoelectronics and Biomedical Materials. 2(4):267-272.

14. Panda, S. K. and C. Jacob. 2012. "Preparation of Transparent $\mathrm{ZnO}$ Thin Films and their Application in UV Sensor Devices', Solid-State Electronics. 73: 44-50.

15. Park, J., H. Ru, T. Son, and S. Yeon. 2012. "Epitaxial Growth of $\mathrm{ZnO} / \mathrm{InN}$ Core/Shell Nanostuctures for Solar Applications', Applied Physics Express 5:101201-3.

16. Raidou, A., M. Aggour, A. Qachaou, L. Laanab, and M. Fahoume. 2010. "Preparation and Characterisation of $\mathrm{ZnO}$ Thin Films Deposited by SILAR Method'. M. J. Condensed Matter. 12(2):125-130.

17. Shen, L., Z. Q. Ma, C. Shen, F. Li, B. He, and F. $\mathrm{Xu}$. 2010. "Studies on Fabrication and 
Characterization of $\mathrm{ZnO} / \mathrm{p}-\mathrm{Si}$-based Solar Cell', Superlattices.and.Microstructures. 48(4):426-433.

18. Singh, S., H. Kaur, D. Pathank, and R.K. Bedi. 2011. "Zinc Oxide Nanostructures as Transparent Window Layer for Photovoltaic Applications". Digest Journal of Nanomaterials and Biostructures. 6(2):689-698.

19. Suchea, M., S. Christoulakis, K. Moschovis, and G. Kiriakidis. 2006. "ZnO Transparent Thin Films for Gas Sensor Applications', Thin Solid Films. 515: 551-554.

20. Stern, F. Quoted by Anuar, K., J.H. Mohd, R.Y. Mohd, W. Tan, H.A. Abdul, S. Ho and N. Saravanan. 2010. "Chemical Bath Deposition of NiSe Thin Films from Aqueous Solution', Kuwait J. Sci Eng. 37(2A):63-73.

21. Sutthana, S., N. Hongsith, and S. Choopun. 2010. "AZO/Ag/AZO Multilayer Films Prepared by Dc Magnetron Sputtering for Dye-Sensitised Solar Cell applications"'. Current Applied Physics 10(3):813-816.

22. Tahar, R. B. H. 2005. "Structural and electrical Properties of Aluminium -doped Zinc Oxide Thin Films by Sol-gel Process', Journal of the European Ceramic Society 25(14):3301-3306.

23. Tan, S. T., B. J. Chen, X. W. Sun, W. J. Fan, H. S. Kwok, X. H. Zhang, and S. T. Chua. 2005. "Blueshift of Optical Band Gap in ZnO Films Grown by Metal-Organic Chemical-Vapor Deposition', Journal of Applied Physics 98: 013505-1-8.

24. Teng, X. M., H.T. Fan, S. S. Pan, C. Ye, G.H. Li. 2006. "Photoluminescence of $\mathrm{ZnO}$ Thin Films on Si Substrate with and without ITO Buffer Layer". J. Phys. D: Appl. Physics 39:471-476.

25. Thitima, R., C. Patcharee, S. Takashi, Y. Susumu. 2009. "Efficient Electron Transfers in $\mathrm{ZnO}$ Nanorod Arrays with N719 Dye for Hybrid Solar Cells'. Solid-State Electronics 53(2):176-180.

26. Xu, J. X., X. H. Xiao, F. Ren, and C.Z. Jiang. 2010. "Controlling the Microstructure of $\mathrm{ZnO}$ Nanaparticles Embedded in Sapphire Zn Ion Implantation and Subsequent Annealing". Nuclear Instruments and Methods in Physics Research
Section B: Beam Interactions with Materials and Atoms 268(17-18):2702-2705.

27. Young-Sung, K., T. Weon-Pil, and S. Su-Jeong. 2005. "Effect of Preheating Temperature on Structural and Optical Properties of $\mathrm{ZnO}$ Thin Films by Sol-gel Process', Thin solid Film 491: $153-160$

\section{BIOGRAPHIES}

Isaac Nkrumah is a lecturer at Department of Physics, Kwame Nkrumah University of Science and Technology (KNUST). He holds M.Sc in Physics. He research interest is thin film technology and renewable energy.

Dr. Francis K. Ampong is a senior Lecturer at Department of Physics, KNUST. He holds Ph.D in Physics. His field of specialization is Synthesis and Characterization of some semiconducting thin films (Binary and Ternary systems) for photovoltaic applications.

Dr. Bright Kwakye-Awuah is a lecturer at the Department of Physics, KNUST. He holds Ph.D in Physics. His research interest is synthesis, characterization and applications of porous inorganic materials.

Professor R.K. Nkum is a Professor at the Physics Department, KNUST. He holds D.Sc. in Physics and he is currently the Provost, College of Science. His research interest is in Dielectric and ferroelectric properties of materials, Superconducting and normal properties of $\mathrm{Bi}$ based systems, transport and optical properties of semiconducting thin films and magnetic properties of materials.

Professor Francis Boakye is a Professor at the Physics Department, KNUST. He holds Ph.D. in Physics. His field of specialization is; Synthesis and Characterization of thin solid films (Binary and Ternary systems). 